\title{
Design of PV System for Mobile Tele-Communication Tower
}

\author{
Dewansh Chauhan ${ }^{1}$, Mohit Hazari ${ }^{2}$, Jasmeet Inamdar ${ }^{3}$, Abrar Kadri ${ }^{4}$ \\ $\mathbf{1 , 2 , 3 , 4}$ B.Tech Electrical Engineering \\ Indus University, Ahmedabad. \\ Gujarat, India.
}

\author{
Dr. Sweta Shah 5 \\ ${ }^{\mathbf{5}}$ Asst. Professor \\ Indus University, Ahmedabad. \\ Gujarat, India.
}

\author{
Sohel Patel ${ }^{6}$ \\ ${ }^{6}$ Senior Project Manager \\ Kanoda Energy System Pvt. Ltd.
}

\begin{abstract}
This paper aimed at developing a procedure for the design of PV system for Mobile Tele-communication tower using the Google SketchUp Software. The output of this project was also estimated using Google SketchUp software and calculated with PV watts; The design of PV system was done with all standard measures. The project began with a collection of site data. In this paper the standard procedure developed was affirm in the design of a mobile Tele-communication tower. This paper contains the different site survey procedure and designs by Google SketchUp that are required for the implementation of PV system for mobile Tele-communication tower.
\end{abstract}

Keywords- Survey validation, Google SketchUp design, Renewable power, $P V$ watts, Solar panel

\section{INTRODUCTION}

Nowadays conventional sources are rapidly depleting. Moreover, the cost of energy is rising and therefore solar energy is one of the most economical and exploitable renewable sources of energy that can be harnessed for generation of power. There are several advantages of using solar energy like low establishment period, no raw material expenses, non-polluting and renewable form of energy, etc. India has very good conditions for the development of photovoltaic solar power systems due mainly the geographical location and it receives solar radiation almost throughout the year, which amounts to $3000 \mathrm{~h}$ of sunshine.

As we already know that the majority of Mobile Telecommunication Towers don't have electricity connection from grid as they are located in remote locations throughout the country. Hence, they rely on Diesel generator, Batteries and now Solar PV. Even if grid is available due to current electricity infrastructure, grid availability is 24 hours with reliable consistent output is always a question.

Now, If we install PV system for mobile Tele-communication towers then we can save a fair amount of diesel plus the PV system is harmless to nature; Now the approx. land acquired or Leased for each mobile Tower on an average is between $10 \times 10 \mathrm{~m}$ and $15 \times 15 \mathrm{~m}$ and tower infrastructure space requirement is $5 \times 5 \mathrm{~m}$ and if there is an availability of additional space one may plan to install Solar PV if site conditions are suitable.

Hence, we have validated mobile telecom site at off grid location and performed the following exercise.

1. Validate the survey forms.

2. Finalise the Solar PV capacity using shadow analysis in Google SketchUp.

3. Calculation of unit generation in PV watts calculator.

\section{STRUCTURE AND DESCRIPTION OF SURVEY FORM (Validation processes)}

The structure of the survey form is shown below:

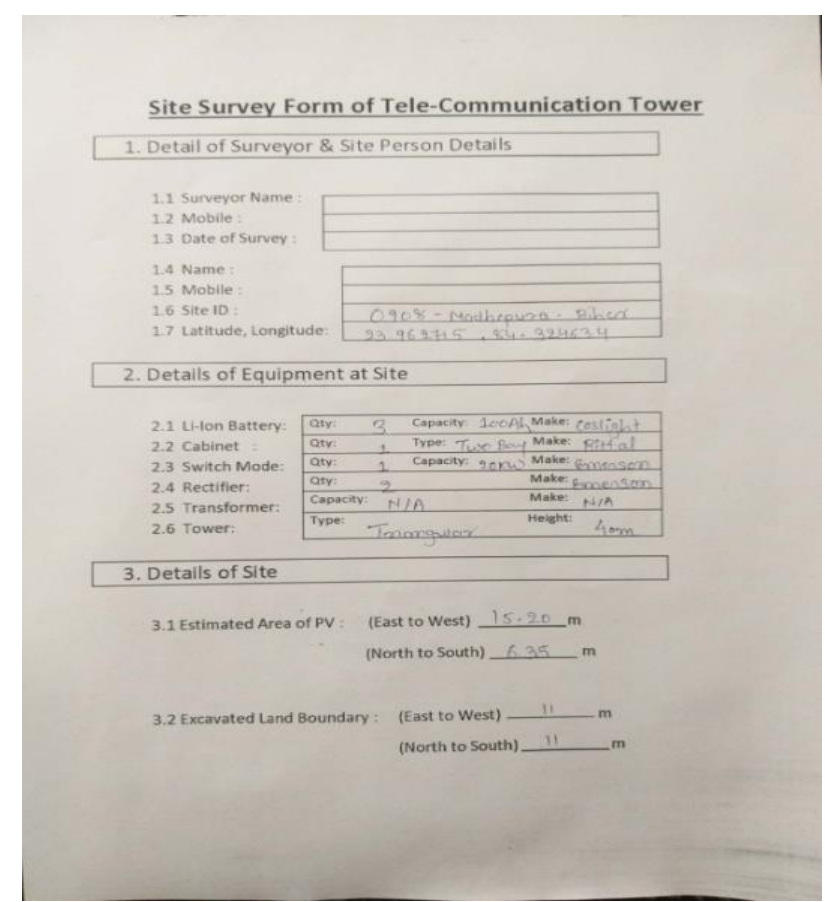

Fig. 1: Survey form pg.1 
Section-1: Details of Surveyor \& Site Person Details:

In this section the basic details of the surveyor and site person has to be mentioned by the surveyor himself to track the site details easily. The date of the survey is to be mentioned in Sec 1.3 and it is very important because if in future any problem arises then we can track the data easily.

The Site-ID is very important aspect which has to be mentioned in Sec 1.6 as it is helpful to identify the different sites located anywhere in PAN India.

Example of site-ID,

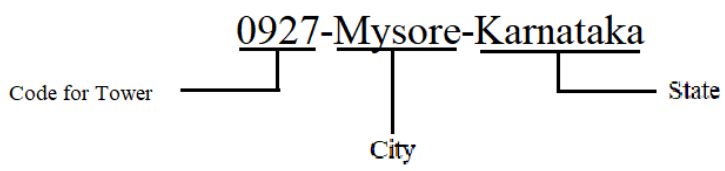

Fig. 2: Site-ID

Latitude-Longitude is another very important aspect which has to be mentioned in Sec 1.7 by the surveyor, according to this Lat-Long the validation team can get the exact location of the site with the help of Google Earth as shown in Fig. 3 and from this also they can get the idea of the location of the tower and the surroundings of the tower (like trees, houses, huts, well etc.).

Also they can get the idea of the tilt angle from the Lat-Long and they can verify the azimuth angle given by the surveyor in Sec 3.4 (Fig.4).

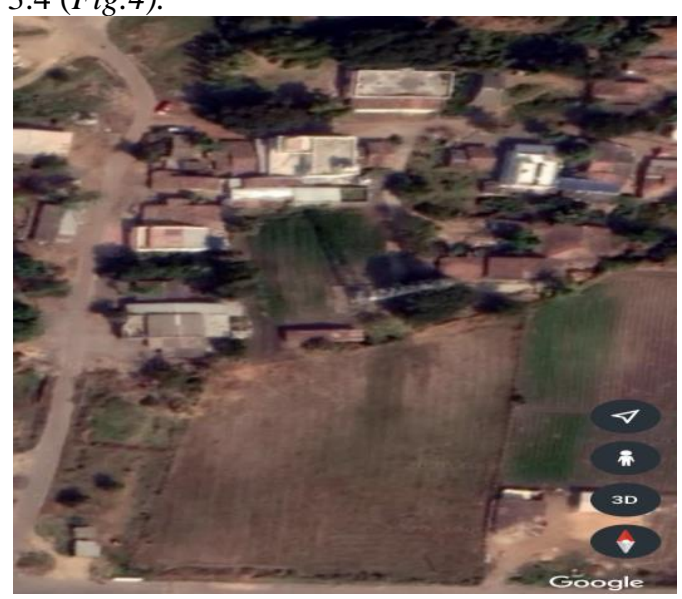

Fig. 3: Site Location

Section-2: Details of Equipments at Site:

In this section the details of the site equipments like Quantity, Capacity, Make, Type are required. All these details must be filled by the surveyor in any circumstances.

Section-3: Details of Site:

In this section all the details of the site have to be mentioned by the surveyor as required in the partial sections of the Section 3 (Figl). The surveyor must mention all the dimensions in meter $(\mathrm{m})$.

\section{Importance of Each Section:}

In section 3.1 the estimated area of PV from East to West and North to South have to be mentioned by the surveyor as per the land acquired by the company.
In section 3.2 the Excavated land boundary is the area which is covered by the tower has to be mentioned by the surveyor from East to West and North to South.

3.3 Total Acquired/Lease Boundary: (East to West) $15.20 \mathrm{~m}$ (North to South) 15.20

3.4 Solar Azimuth: $17^{\circ}$ SE (w.r.t South)

3.5 Shadow Casting Objects : Yes $\square$ No $\square$

\begin{tabular}{|c|c|c|}
\hline East to South & South & West to South \\
\hline Objects: Tree & Tree & Objects: $E B$ pole \\
\hline Dimensions : & Dimensions : & Dimensions: \\
\hline 1) $98 \times 4 \mathrm{w} \times 7 \mathrm{H}$ & 1) $2.51 \times 3 \mathrm{~W} \times$ 느 $\mathrm{H}$ & 1) $2 L \times C, 3 W \times \exists H$ \\
\hline 2) ${ }^{L x}{ }^{L} W_{x}{ }_{-}{ }^{H}$ & 2) _Lx $L W x{ }^{-H}$ & 2) ${ }^{L \times}{ }^{-W \times}-^{H}$ \\
\hline 3) $L L x \_W x-H$ & 3) _L Lx_Wx $\quad H$ & 3) $\_L x \_W x-H$ \\
\hline
\end{tabular}

3.6 Fencing Type and Height

3.7 Location for New Cabinet : Yes $\square$ No $\square$

3.8 Earth Pit Location: Yes $\square$ No $\square$

3.9 Cable Route : Yes $\square$ No $\square$

\section{Meter Details}

4.1 Distribution Company :

4.2 Meter No:

4.3 Meter Type :

4.4 Voltage Reading

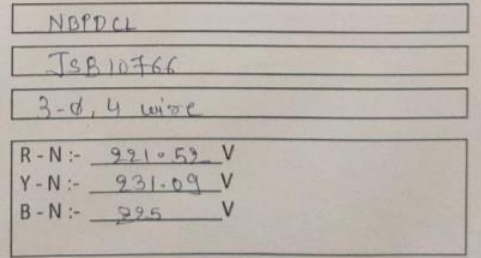

Fig. 4: Survey form pg.2

In section 3.3 (Fig.4) the Total acquired/Leased boundary is the area owned by the company and the surveyor has to mention it from East to West and North to South.

In section 3.4 (Fig.4) the surveyor has to mention the Azimuth i.e tilt angle of the site with respect to south. For example as shown in Fig.5, if the surveyor has mentioned the $-30^{\circ}$ the plot is tilted towards east side with respect to south, if the surveyor has mentioned $0^{\circ}$ then the plot is at true south and if the surveyor has mentioned $+30^{\circ}$ then the plot is tilted at west side with rest to south.
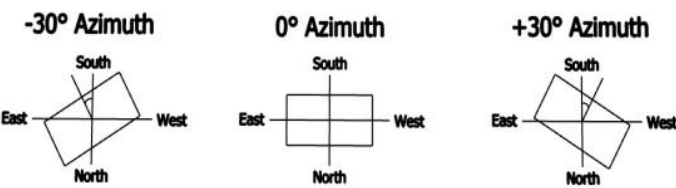

Fig. 5: Solar azimuth 
In section 3.5 (Fig.4) the surveyor has to mention that if there is any shadow casting object present at the site or not. If there is any shadow casting object present at the site then surveyor has to tick in the checkbox given for 'Yes' and the surveyor has to mention whatever the object present at the site and also fill the dimensions of that object.

The section 3.6 (Fig.4) is given for the fencing, if the fencing is available at the site the survey has to mention the type and height of the fencing.

In section 3.7 (Fig.4) the surveyor has to mention that if there is location available for new cabinet at the site or not and if the location is available then the surveyor has to show the location in the $2 \mathrm{~d}$ drawing.

In section 3.8 (Fig.4) the surveyor has to mention that if the earth pits are visible or not and if the Earth pits are visible then the surveyor has to show it in the $2 \mathrm{~d}$ drawing.

In section 3.9 (Fig.4) the surveyor has to mention the cable route if seen at the site and also has to mention in the $2 \mathrm{~d}$ drawing.

\section{Section-4: Meter Details}

In this section the surveyor has to mention the meter details like Distribution company, Meter number, Type of meter and voltage reading of each phase.

\section{Section-5: Additional Remarks}

In this section the surveyor has to write the additional remark as shown in Fig.6

$\begin{aligned} & \text { 5.Additional Remarks } \\ \rightarrow \text { ondy } 2 \text { Eurth Pits are visible. } & \\ \rightarrow \text { (able route is not visible. } & \end{aligned}$

Fig. 6: Remarks

Section-6: 2D Drawing

In this section the surveyor has to draw the $2 \mathrm{D}$ drawing according to the actual site without any mistake and the surveyor has to make sure that anything should not left while making 2D drawing because the design work depends on this $2 \mathrm{D}$ drawing.

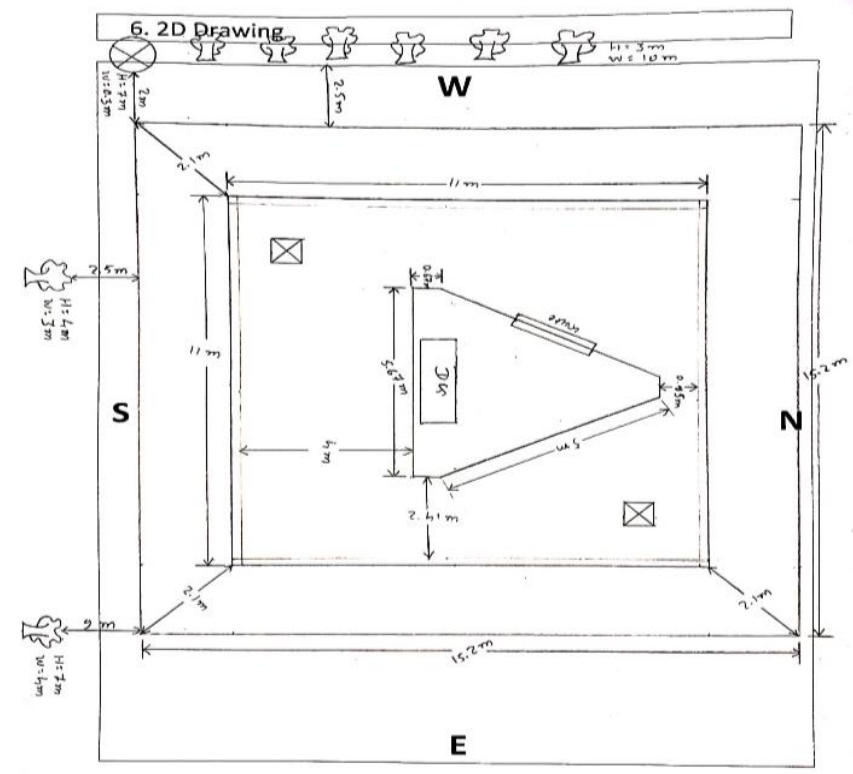

Fig.7: 2D drawing
Preparation of Query Sheet:

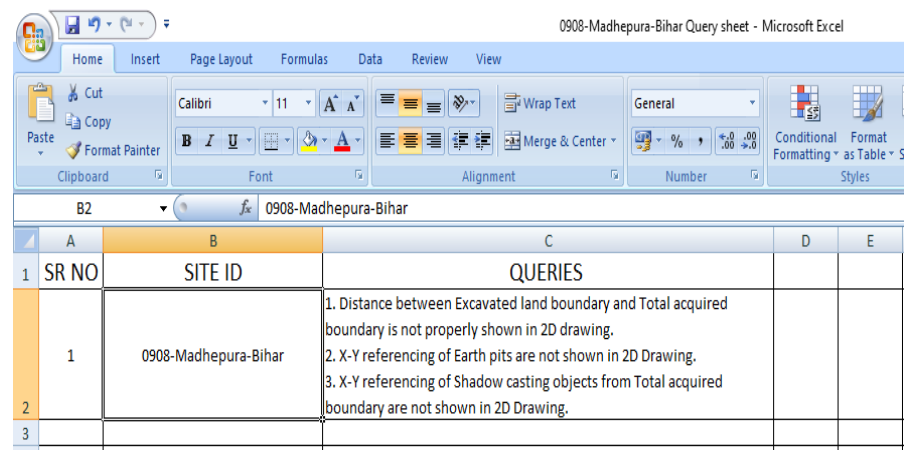

Fig.8: Query sheet

After the survey data validation if validation team does not find any query then the form directly goes into design process but if the query is found in the survey form then the excel sheet is prepared and the queries are sent to the surveyor so that surveyor will resolve the queries and revert back to us, like in this site there are queries found in the 2D drawing which are mentioned in the query sheet as shown in Fig.8.

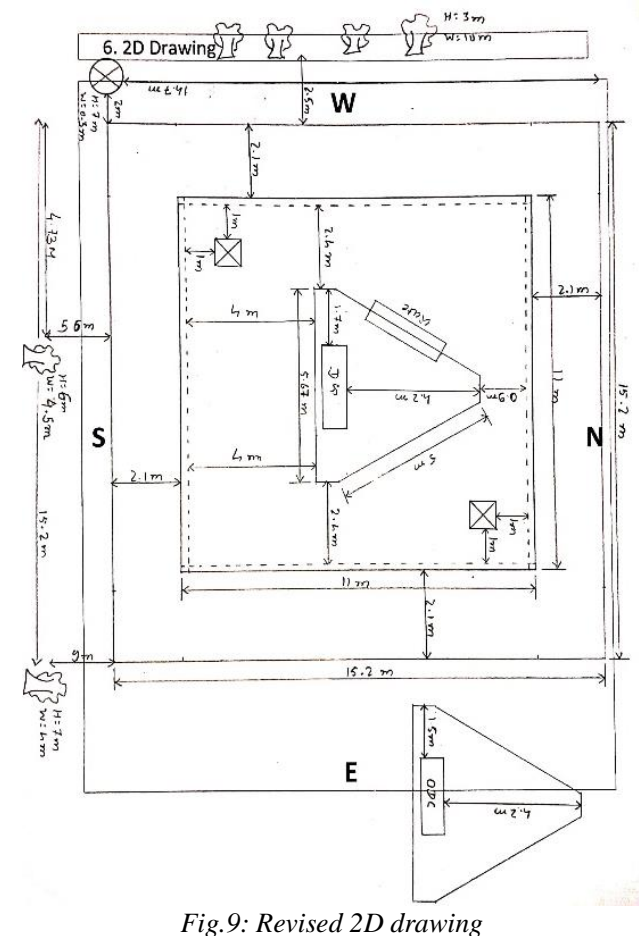

This is a final $2 \mathrm{~d}$ drawing sent by the surveyor after resolving the queries.

\subsection{Basic Information About Existing Site Equipment}

(1) Tower: -

Lattice Tower is used for such system and these towers are freestanding and segmental designed with rectangular or triangular base steel lattices. This type of tower structure can be useful in circumstances, which require modifications such as mounting large number of panel or dish antennas. 
(2) Cabinet for Equipment: -

Cabinets are mainly used to contain the equipment like battery, rectifiers and SMPS etc. and it is found mainly in two types: - 1) single door and 2) double door.

Degree of Protection is IP65 and above in which the first digit indicates the level of protection that the enclosure provides against access to hazardous parts and the second digit defines the shield of the equipment inside the enclosure against various forms of humidity (drips, sprays, submersion etc).

(3) Battery: -

Batteries are used to store and supply electrical energy to telecom towers when grid power fails. When battery lifespan is extended, the need for towers to depend on costly diesel-fuelled generators (DG) becomes lesser.

Types of Batteries: - 1) Lead-Acid

\section{2) Lithium-ion \\ 3) Saltwater}

Nowadays Lithium-Ion batteries are more used because Lithium-ion, or li-ion, batteries have more than double the life of traditional lead-acid batteries so telecom tower companies are increasingly installing lithium-ion batteries for uninterrupted power supplies to their towers.

(4) Switch Mode Power Supply (SMPS): -

SMPS is the brain of the Mobile Tele-Communication tower. It Controls, Regulates and provides Electrical energy to mobile tower load from different energy sources like Diesel generator, Grid, Battery and Solar PV.

(5) Rectifier: -

Rectifier systems are used to convert the AC power to DC for the communications equipment and to charge the batteries continuously so that they can supply the power to the communications equipment in case of $\mathrm{AC}$ power loss.

(6) Diesel Generator (DG): -

The diesel generator is an equipment which is used for applications that requires more power and continuous operation.

They convert the fuel into electrical energy, through the combustion of diesel, Diesel generators require regular maintenance to function properly.

\subsection{Existing Working of Tele-Communication Tower and their Drawbacks}

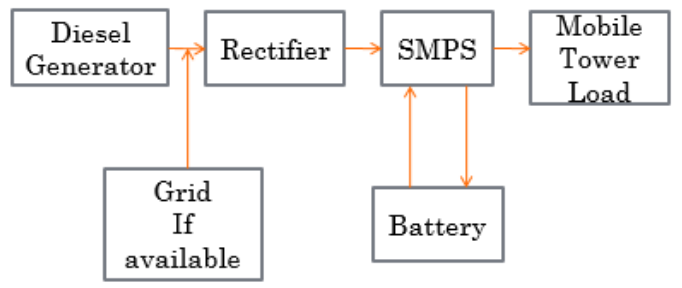

Fig.10: Block diagram of existing working system
The existing system works on the DG set in which the energy is converted from diesel into the electrical energy.

The electrical energy we are getting from such system is AC in nature but the Tele-communication tower runs on DC power.

So, the rectifiers are used to convert the AC power into DC power and also used to charge the batteries continuously, when the batteries are fully charged then the Telecommunication system works on batteries only and all this is maintained by SMPS (Switch Mode Power Supply).

As level of batteries reaches to a critical limit then the system works back on Diesel generator.

Drawbacks:

-System consumes fuel which is costly.

-More Equipment are used.

-Losses are more due to more conversion stages.

-Harmful to environment.

\subsection{Proposed Working of Tele-Communication Tower and their advantages}

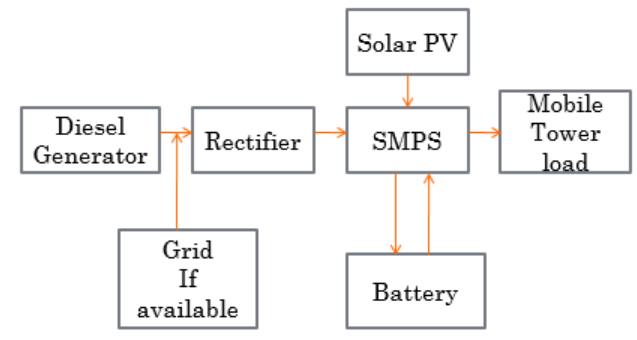

Fig.11: Block diagram of proposed working system

The proposed system will work on Solar system in which the power required to run the mobile Tele-communication tower will be directly taken from the solar system which is already DC in nature.

Batteries are directly charged from the PV system so the conversion becomes less.

Advantages:

-No fuel is required to run the system.

-No conversion losses

-No harmful to nature.

\subsection{Different types of Solar PV Modules}

There are 3 main types of PV modules: -

1. Mono-crystalline

2. Polycrystalline

3. Thin film

But the mono-crystalline panels are used mostly, because its efficiency and performance are much better than polycrystalline and thin film.

The initial cost of mono-crystalline is higher than polycrystalline and thin film. 
2.5 How to decide the plant capacity

$1 \mathrm{KW}$ Solar PV generally gives 3.5 to $4 \mathrm{KWH}$ per Day if proper tilt and azimuth is obtained.

Mobile tower works 24 hours, generally 24 hours consumption is between 35 to 70 Units depending on tower type and equipment installed to provide network coverage.

Based on common plot area recognized so far 7.5 / 9 / 10.5 KW Solar PV can be installed.

\begin{tabular}{|c|c|c|c|}
\hline $\begin{array}{c}\text { PV System } \\
\text { Size }\end{array}$ & $\begin{array}{c}\text { Unit } \\
\text { Requirement }\end{array}$ & $\begin{array}{c}\text { Solar PV } \\
\text { Generation }\end{array}$ & $\begin{array}{c}\text { Unit } \\
\text { Consumption } \\
\text { Converted to } \\
\text { Solar }\end{array}$ \\
\hline 7.5 & 50 & $7.5 * 4=30$ & $60 \%$ \\
\hline 9 & 50 & $9 * 4=36$ & $72 \%$ \\
\hline 10.5 & 50 & $10.5 * 4=42$ & $84 \%$ \\
\hline
\end{tabular}

Table 1

Note :- Assumption: Tele-communication tower load is 50 kWh per day.

\section{BASIC CRITERIA FOR SKTCHUP DESIGN}

The steps for the SketchUp design criteria are as follows:

1) Check Placements and Dimensions given in Survey form and total acquired area from Survey form then tower Placement, Gate, DG, ODC, entry gate of plot boundary and all dimensions.

2) Check all dimensions and tower base to total acquired boundary distance then total acquired boundary and excavated land dimensions as per survey form and available distance from tower base to south side total acquired boundary.

3) Check Capacity as per acquired area available then check final installed capacity as per solar capacity table. Minimum 3.8 Meter distance is required to install any solar capacity. Minimum 2-meter distance from tower plinth to Structure Leg should be maintain.

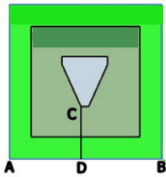

Fig. 12

\begin{tabular}{|c|c|c|c|}
\hline $\begin{array}{c}\text { Sr. } \\
\text { No. }\end{array}$ & $\begin{array}{c}\text { East - West } \\
\text { Distance (A- } \\
\text { B) } \\
\text { (meter) }\end{array}$ & $\begin{array}{c}\text { Tower base to } \\
\text { Acquired area } \\
\text { (C-D) (meter) }\end{array}$ & $\begin{array}{c}\text { Solar } \\
\text { Capacity } \\
\text { (kW) }\end{array}$ \\
\hline 1. & 11 to 12.8 & $>5.2$ & 7.5 \\
\hline 2. & 12.8 to 14.8 & $>5.2$ & 9 \\
\hline 3. & $>14.8$ & $>5.2$ & 10.5 \\
\hline 4. & 11 to 12.8 & $>3.8 \&<5.2$ & 3.75 \\
\hline 5. & 12.8 to 14.8 & $>3.8 \&<5.2$ & 4.5 \\
\hline 6. & $>14.8$ & $>3.8 \&<5.2$ & 5.25 \\
\hline 7. & Any & $<3.8$ & 0 \\
\hline
\end{tabular}

Table 2
4) Identify Shadow casting objects on SE, S and SW side from photos. Then check earth pits around the tower. Then check obstacles like EB pole, fencing, Meter box, Water tank within acquired boundary.

5) Verify Azimuth angle. Make sure that azimuth should be less than $45^{\circ}$. Then verify azimuth as per the survey form and also in Google earth.

6) Check Shadow Analysis.Do shadow analysis for all months from 09:00 AM to 04:00 PM time slot and check with design. Consider variation in shadow free timing if any and update it in query.

\subsection{PV capacity finalization}

PV capacity should be finalized by considering these three factors:

1) Available acquired area for solar installation.

2) PV area (East to West distance and North to South distance of Tower base to acquired boundary).

3) Shadow free area available.

\subsection{SketchUp design for the specific site}

In this particular site 0908-Madhepura-Bihar two designs are proposed by the designer because the shadow of trees and EB pole is casting on the installation area as shown in Fig.13.

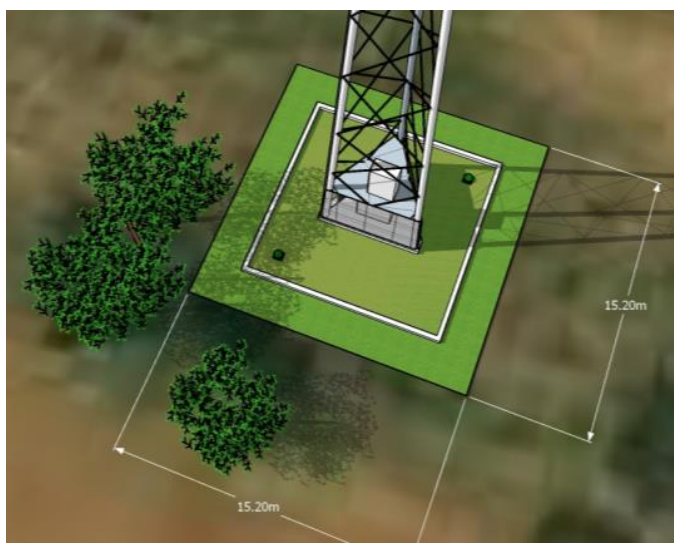

Fig.13: Shadow analysis

In design capacity-1 the installation capacity is $5.25 \mathrm{KW}$ without any modifications at site as shown in Fig.14.

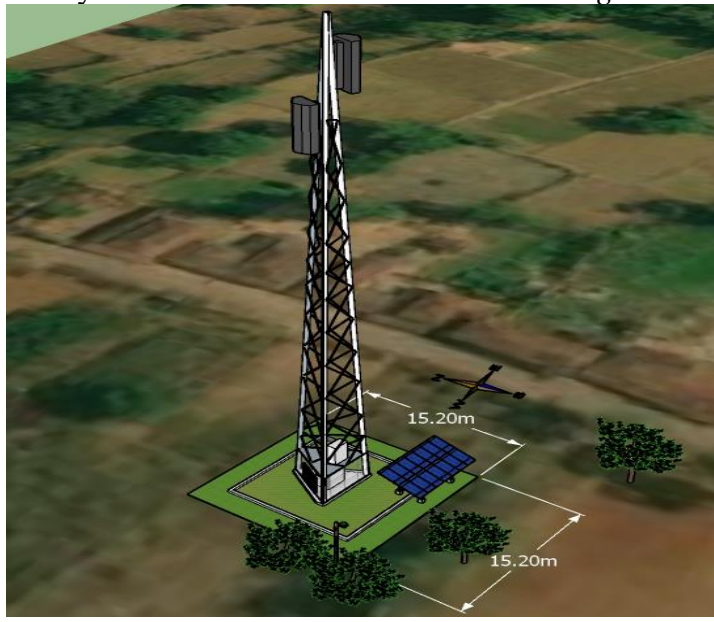

Fig.14: Design Capacity - 1 
$-5.25 \mathrm{KW}$ is shadow free from 09:00 AM to 02:00 PM throughout the year.

-Units generated yearly: $8,138 \mathrm{kWh}$ per year

-Daily Generation: $22 \mathrm{kWh}$

In design capacity-2 modifications are made at site like trimming trees and relocating EB pole, then the installation capacity can be increased to $10.5 \mathrm{KW}$ which is shown in Fig.15.

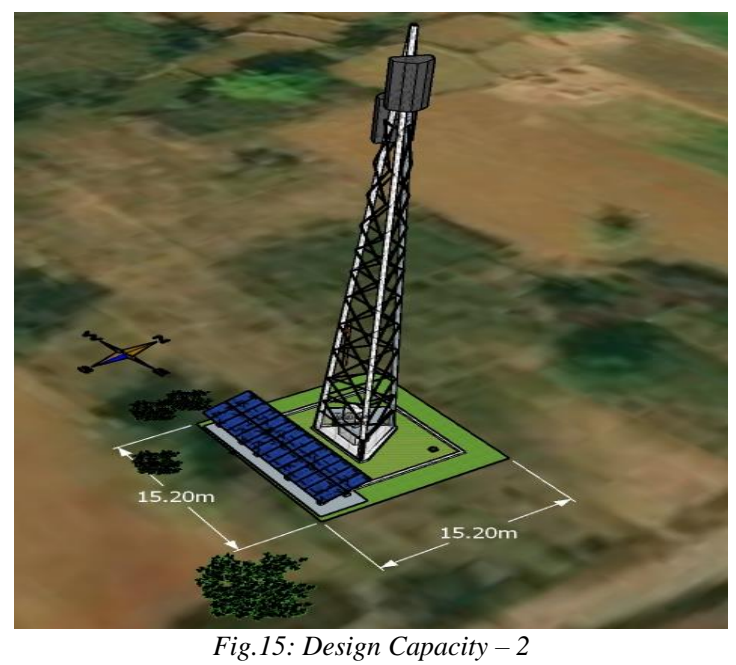

After modification like trimming trees and relocating EB pole and increasing PV system capacity, $10.5 \mathrm{KW}$ is shadow free from 09:00 AM to 04:00 PM throughout the year.

-Units generated yearly: $16,277 \mathrm{kWh}$ per year

-Daily Generation: $44 \mathrm{kWh}$

\begin{tabular}{|c|c|c|c|c|c|c|c|}
\hline $\begin{array}{c}\text { Sr } \\
\text { No }\end{array}$ & Site ID & $\begin{array}{c}\text { Area } \\
\text { available } \\
\text { for solar }\end{array}$ & \multicolumn{2}{|c|}{$\begin{array}{c}\text { Solar PV } \\
\text { Capacity }\end{array}$} & \multicolumn{2}{|c|}{$\begin{array}{c}\text { Shadow free } \\
\text { timing }\end{array}$} & $\begin{array}{c}\text { Modification } \\
\text { required for } \\
\text { DC-2 }\end{array}$ \\
\hline 1. & $\begin{array}{c}\text { Madhepura } \\
\text {-Bihar }\end{array}$ & $\begin{array}{c}15.2 \times 6.35 \\
\mathrm{M}\end{array}$ & 5.25 & 10.5 & $\begin{array}{c}9 \text { AM } \\
\text { to 2 } \\
\text { PM }\end{array}$ & $\begin{array}{c}\text { AM } \\
\text { to 4 } \\
\text { PM }\end{array}$ & $\begin{array}{c}\text { Trimming } \\
\text { trees and } \\
\text { relocating EB } \\
\text { pole }\end{array}$ \\
\hline
\end{tabular}

Table 3: Summary of Shadow Analysis using Google SketchUp

\subsection{PV watts Calculation}

PV Watts Calculator is an interactive web application that allows homeowners, installers and manufacturers to easily develop estimates of the performance of potential PV installations at specific locations. Results are pretty accurate as its developed and maintained by National Renewable Energy Laboratory (NREL-USA), Output is given in $\mathrm{kWh}$ (Electrical Units generated for use).

Steps to be considered while calculating PV watts:

1) Latitude and longitude should be proper for accurate results.

2) DC Capacity should be mentioned in PV watts calculator to get the generating units per annum.
3) Tilt angle is selected according to the location and this tilt angle must be proper to get the maximum generation.

4) Proper azimuth must be specified to get the accurate output.

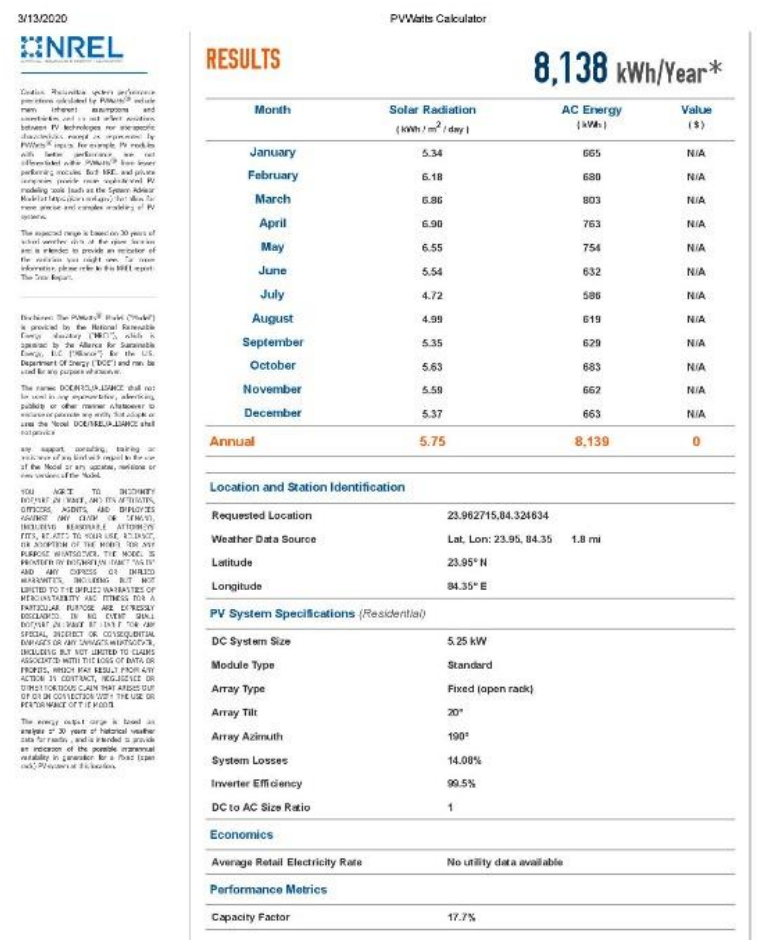

Fig.16: PV watts calculation for DC-1

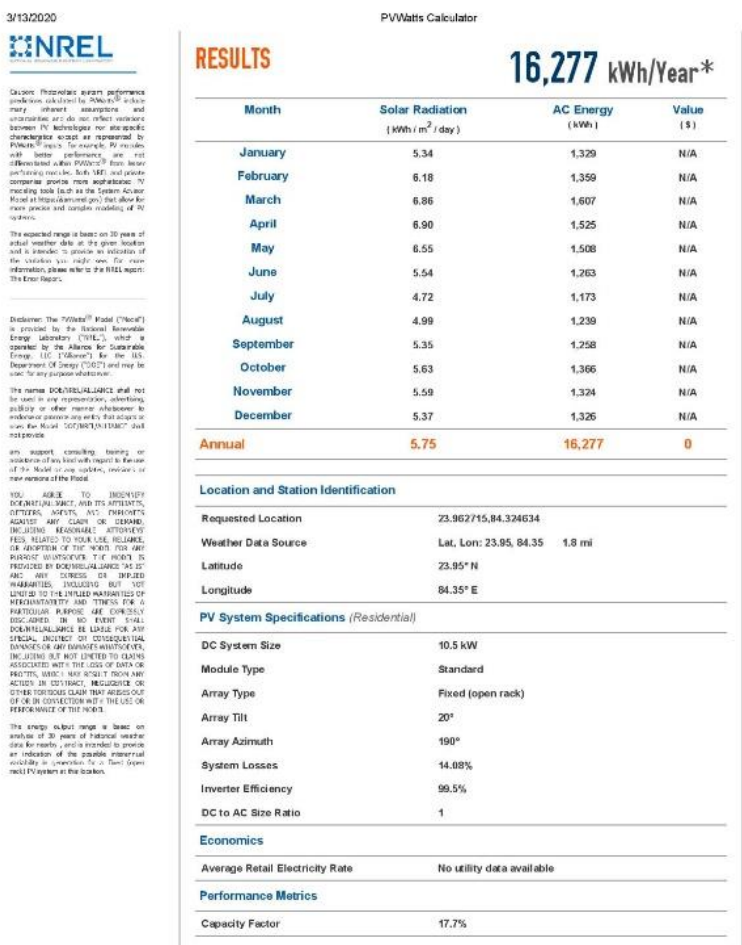

Fig.17: PV watts calculation for $D C-2$ 
3.4 Selection criteria between $d c-1 \& d c-2$

\begin{tabular}{|c|c|c|c|c|c|c|}
\hline $\begin{array}{c}\text { Sr. } \\
\text { No. }\end{array}$ & Site ID & $\begin{array}{c}\text { Capacity } \\
\text { DC (KW) }\end{array}$ & $\begin{array}{c}\text { kWh } \\
\text { generated } \\
\text { per year }\end{array}$ & $\begin{array}{c}\text { kWh } \\
\text { generated } \\
\text { per day }\end{array}$ & $\begin{array}{c}\text { Savings } \\
(\%)\end{array}$ \\
\hline 1. & $\begin{array}{c}\text { 0908- } \\
\text { Madhepura- } \\
\text { Bihar }\end{array}$ & 5.25 & 8,138 & 22 & 44 \\
\hline
\end{tabular}

Table 4: Design capacity-1 without modification

\begin{tabular}{|c|c|c|c|c|c|}
\hline $\begin{array}{c}\text { Sr. } \\
\text { No. }\end{array}$ & Site ID & $\begin{array}{c}\text { Capacity } \\
\text { DC }(\mathrm{KW})\end{array}$ & $\begin{array}{c}\mathrm{kWh} \\
\text { generated } \\
\text { per year }\end{array}$ & $\begin{array}{c}\mathrm{kWh} \\
\text { generated } \\
\text { per day }\end{array}$ & $\begin{array}{c}\text { Savings } \\
(\%)\end{array}$ \\
\hline 1. & $\begin{array}{c}\text { 0908- } \\
\text { Madhepura- } \\
\text { Bihar }\end{array}$ & 10.5 & 16,277 & 44 & 89 \\
\hline
\end{tabular}

Table 5: Design Capacity -2 with modifications

\section{CONCLUSION}

Hence a study was concluded for $5.25 \mathrm{~kW}$ and $10.5 \mathrm{~kW}$ off grid solar power plant for Mobile Tele-communication Tower. Concluding the survey validation with all necessary aspects, These designs was made in Google SketchUp and shadow analysis of the sites are also done using the same software. Among these two designs the design with capacity $10.5 \mathrm{~kW}$ which is Design capacity-2 was approved for installation, as relocation of EB pole is possible along with trimming of trees as approved by Distribution company and owner respectively. This capacity will save $89 \%$ as shown in Table 5.

\section{REFERENCE}

[1] https://www.kanoda.com/

[2] Design on Google SketchUp

[3] Google Earth Pro

[4] Calculation of unit generation on pvwatts.nrel.gov

[5] https://www.pv-tech.org/news/voltalia-to-install-solar-andbatteries-at-myanmar-telecom-towers

[6] https://en.wikipedia.org/wiki/Solar_power_in_India

[7] https://www.techuva.com/telecom.html 